\title{
Endoscopic Ultrasound-guided Fine Needle Aspiration for the Diagnosis of Duodenal Stenosis Due to Urothelial Carcinoma
}

\author{
Iori Motoo ${ }^{1}$, Takayuki Ando ${ }^{1}$, Hiroshi Mihara ${ }^{1}$, Shinichi Tanaka ${ }^{2}$, Sohachi Nanjo ${ }^{1}$, \\ Shinya Kajiura ${ }^{1}$, Haruka Fujinami ${ }^{1}$, Kosuke Takahashi ${ }^{1}$ and Ichiro Yasuda ${ }^{1}$
}

\begin{abstract}
:
Upper tract urothelial carcinoma (UTUC) initially presents with hematuria and hydronephrosis. We report a case of UTUC presenting with initial findings of duodenal stenosis before the appearance of hydronephrosis. A 59-year-old man presented with upper abdominal symptoms on his initial visit. Esophagogastroduodenoscopy (EGD) revealed circumferential stenosis at the descending part of the duodenum. However, the underlying cause of duodenal stenosis was unknown as repeated histopathological examinations of endoscopic biopsy specimens showed no specific findings. We then performed endoscopic ultrasound-guided fine needle aspiration (EUS-FNA) of the thickened duodenal wall, and successfully diagnosed duodenal metastasis of UTUC. EUS-FNA is an effective diagnostic method in cases in which the cause of duodenal stenosis is unknown.
\end{abstract}

Key words: urothelial carcinoma, duodenal stenosis, EUS-FNA

(Intern Med 60: 719-724, 2021)

(DOI: 10.2169/internalmedicine.5685-20)

\section{Introduction}

The many causes of duodenal stenosis include both neoplastic and non-neoplastic disease. In cases of duodenal stenosis caused by non-neoplastic disease, including retroperitoneal panniculitis, Crohn's disease, tuberculosis, and vasculitis, stenosis is induced by chronic inflammation (1-3). On the other hand, neoplastic stenosis results from the growth of duodenal or metastatic duodenal cancer, direct invasion of pancreatic or bile duct cancer into the duodenum, or infiltration of peritoneal dissemination into the duodenal wall (4-7). The identification of primary cancer is therefore challenging for clinicians when computed tomography (CT) does not identify a primary site, and endoscopic biopsy reveals no cancer cells.

We herein report a case of upper tract urothelial carcinoma (UTUC) presenting with duodenal stenosis resulting from lymphatic metastasis to the duodenal wall. However, the diagnosis was difficult because repeated endoscopic bi- opsies were negative for cancer due to poor mucosal change, and CT scans obtained at the initial visit showed no urinary tract lesions or hydronephrosis, as secondary signs of advanced disease (8). Finally, endoscopic ultrasound-guided fine needle aspiration (EUS-FNA) revealed cancer cells in the duodenal wall, and a primary diagnosis of UTUC was reached based on an immunohistochemical study.

\section{Case Report}

A 59-year-old man was admitted for abdominal fullness, vomiting, and body weight loss of $5 \mathrm{~kg}$. A physical examination revealed upper abdominal distension and a laboratory examination revealed mild renal dysfunction without hematuria or proteinuria. Abdominal CT showed wall thickening of the descending part of the duodenum at the initial visit, suggesting duodenal stenosis as the underlying cause of the symptoms (Fig. 1a). In addition, the concentration of fatty tissue surrounding the right kidney was slightly increased. No other abnormal findings were observed. Consequently,

${ }^{1}$ Third Department of Internal Medicine, University of Toyama, Japan and ${ }^{2}$ Diagnostic Pathology, University of Toyama, Japan Received: June 23, 2020; Accepted: August 3, 2020; Advance Publication by J-STAGE: September 19, 2020 Correspondence to Dr. Iori Motoo, iori4869@med.u-toyama.ac.jp 


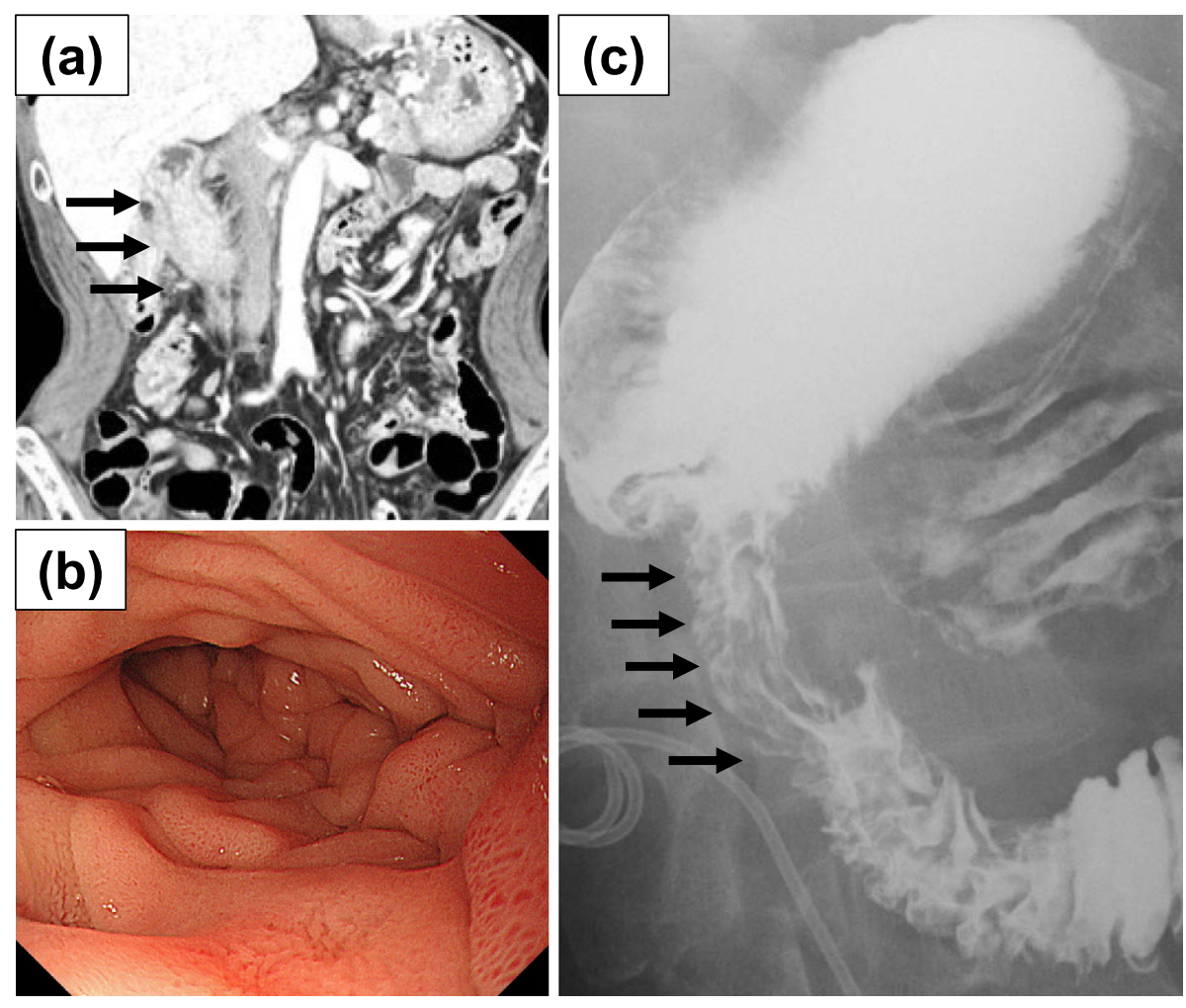

Figure 1. The appearance of the duodenal stenosis on the initial visit. (a) Abdominal computed tomography on the first visit showed thickening of the duodenal wall with no other specific findings. (b) Esophagogastroduodenoscopy revealed circumferential stenosis without erosion or ulceration at the descending part of the duodenum. (c) Hypotonic duodenography using barium revealed smooth stenosis in the lumen (arrows).

esophagogastroduodenoscopy (EGD) and hypotonic duodenography were performed. These tests revealed circumferential stenosis of $3 \mathrm{~cm}$ in length with multiple red spots at the descending part of the duodenum (Fig. 1b, c). However, the underlying cause of the duodenal stenosis could not be determined because no specific findings were observed in the histopathological examination of 15 endoscopic biopsy specimens. The patient's serum levels of carcinoembryonic antigen (CEA) and carbohydrate antigen 19-9 (CA19-9) were $3.8 \mathrm{ng} / \mathrm{mL}$ (normal $<3.4 \mathrm{ng} / \mathrm{mL}$ ) and $14 \mathrm{U} / \mathrm{mL}$ (normal $<37 \mathrm{U} / \mathrm{mL}$ ), respectively.

Follow-up abdominal CT three months after the initial visit showed thickening of the right ureter wall and right hydronephrosis (Fig. 2a, b), and retrograde urography revealed irregular ureteral stenosis (Fig. 2c). No abnormal findings of the bile duct or pancreas were observed. The immunoglobulin $\mathrm{G}$ subclass 4 ( $\mathrm{IgG} 4$ ) serum level was $24.3 \mathrm{mg} / \mathrm{dL}$ (normal $11-121 \mathrm{mg} / \mathrm{dL}$ ). Based on these findings, the assumed differential diagnoses were diffuse duodenal cancer with peritoneal dissemination to the ureter or urothelial carcinoma with duodenal metastasis. EUS-FNA of the duodenal lesion and ureteroscopy were therefore performed. EUS showed a thickened duodenal wall (thickness: $5.4 \mathrm{~mm}$ ) and a swollen superior anterior pancreatic lymph node (size: 15 $\mathrm{mm}$ ). EUS-FNA of both lesions was successfully performed using a $22 \mathrm{G}$ needle (Acquire, Boston Scientific, Marlbor- ough, USA) (Fig. 3). In particular, we punctured the thickened duodenal wall at the duodenal bulb at a shallow puncture angle. Finally, a pathological analysis revealed cancer nests in the duodenal wall, which seemed to have spread into the lymphatic vessels. An immunohistochemical analysis revealed that the cancer cells were positive for cytokeratin 7 (CK7), cytokeratin 20 (CK20) and GATA binding protein 3 (GATA3) (Fig. 4). Cancer nests were also identified in the lymph node, which were positive for CK7, CK20 and GATA3 and negative for caudal-related homeobox 2 (CDX 2) (data not shown). These immunostaining characteristics strongly suggested urothelial carcinoma. Additionally, ureteroscopy showed ureteral stenosis with sessile tumor architecture, and a histological examination of biopsy specimens obtained by ureteroscopy showed CK7-, CK20- and GATA3-positive transitional cell carcinoma (Fig. 5). All findings were consistent with those of the duodenal and lymph node specimens, and the final diagnosis was urothelial carcinoma with lymph node and duodenal metastasis. The clinical disease stage, according to the tumor-nodemetastasis staging system of the Union for International Cancer Control, was T4N2M1, stage IV.

The patient received gastrojejunostomy for duodenal stenosis alongside treatment with gemcitabine plus cisplatin. The best response to chemotherapy was stable disease across four cycles of chemotherapy. However, the right hilar lymph 


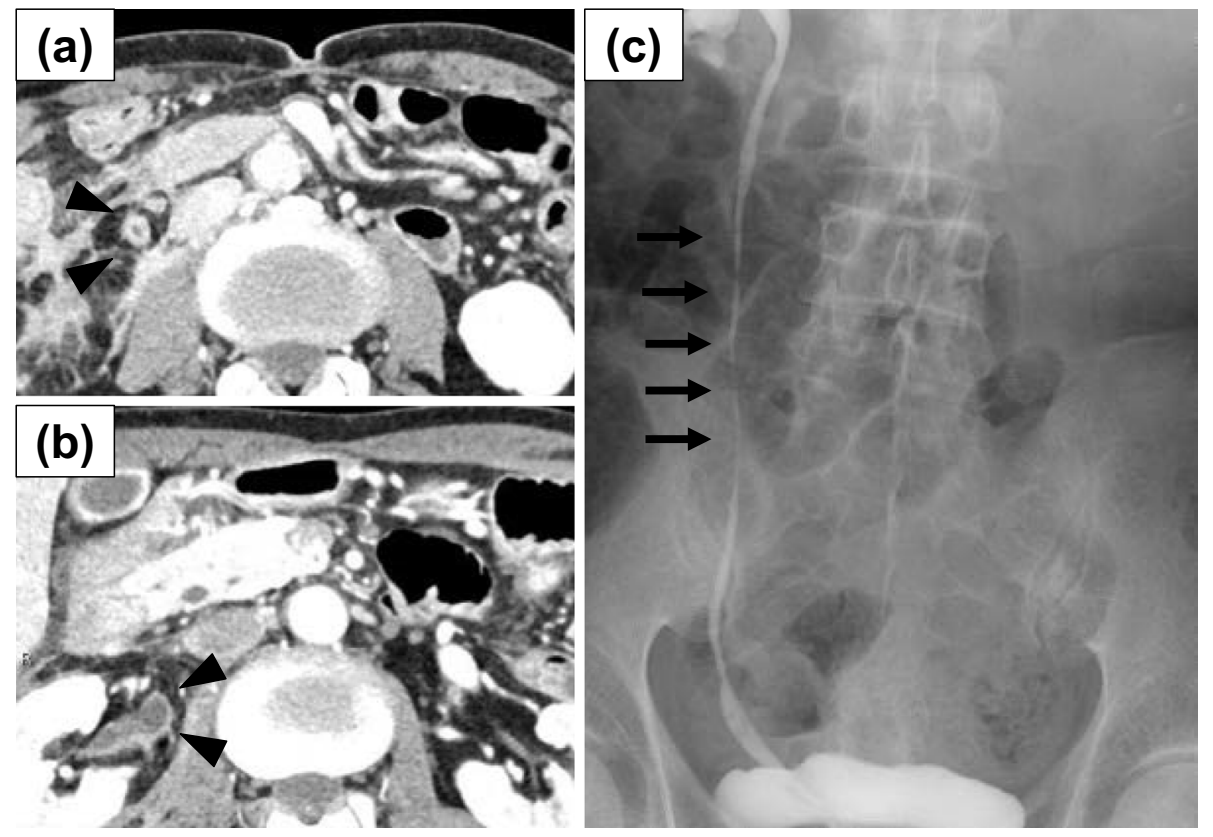

Figure 2. Appearance of the ureteral stenosis at three months after initial visit. (a), (b) Abdominal computed tomography showed right hydronephrosis and wall thickening of the right ureter (arrowheads). (c) Retrograde urography showed irregular ureteral stenosis (arrows).
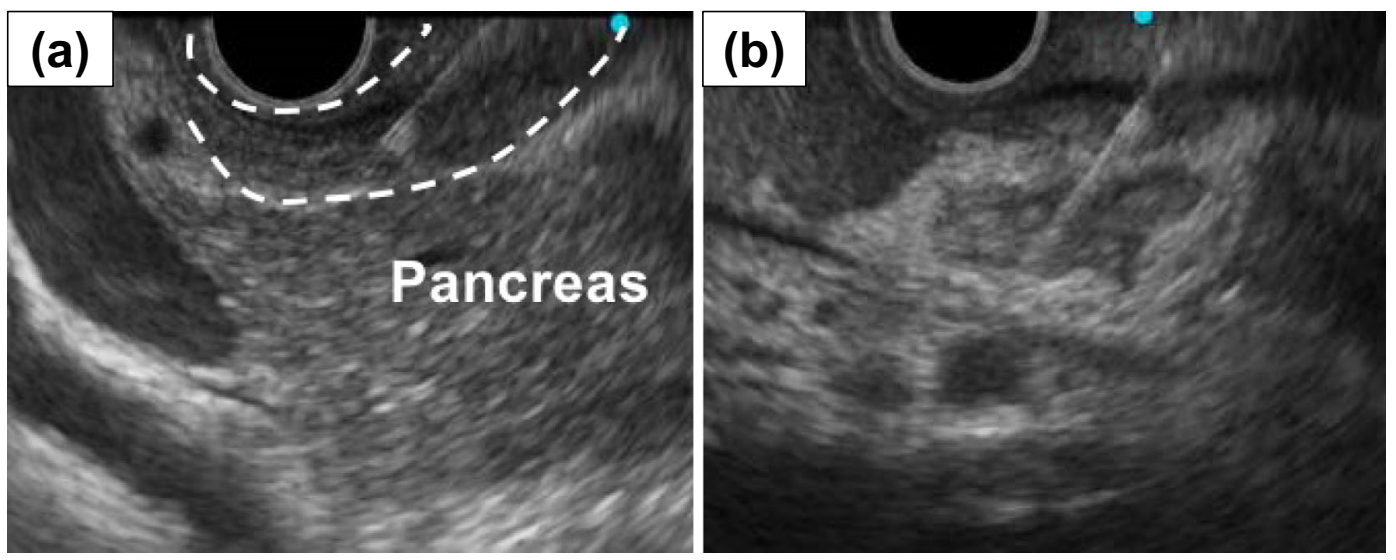

Figure 3. Endoscopic ultrasound-guided fine needle aspiration (EUS-FNA). EUS revealed duodenal thickening (a) and irregular abdominal lymph node swelling (b). FNA of both lesions was successfully performed using a $22 \mathrm{G}$ needle.

nodes progressed five months after the initiation of first-line chemotherapy. Thus, pembrolizumab treatment was initiated.

\section{Discussion}

The initial findings in UTUC are generally visible or nonvisible hematuria and hydronephrosis due to ureter stenosis (8-10), although circumferential stenosis of the duodenum has occasionally been described in previous reports (11-14) (Table). The present case therefore highlights two important clinical points. The first is that upper abdominal symptoms due to duodenal stenosis may appear before hematuria and hydronephrosis; the other is that EUS-FNA was a conclusive minimally invasive method for diagnosing duodenal stenosis of unknown cause. As a result, the patient avoided unnecessary invasive diagnostic surgical procedures and could receive chemotherapy.

Duodenal metastasis from a distant origin is an uncommon event. UTUC usually metastasizes to the lung, liver, and bone with lymph node metastasis (15). The current case showed duodenal metastasis earlier than those organs; thus, we focused on the metastatic pathway of UTUC to the duodenum. Previously, advanced UTUC has been reported to cause duodenal stenosis via direct invasion, and lymphatic and peritoneal dissemination (11-14). Ando et al. demonstrated that cancer cells reached the duodenum through lymphatic metastasis in an autopsy case of recurrent UTUC (12). Their findings revealed that high-grade urothe- 


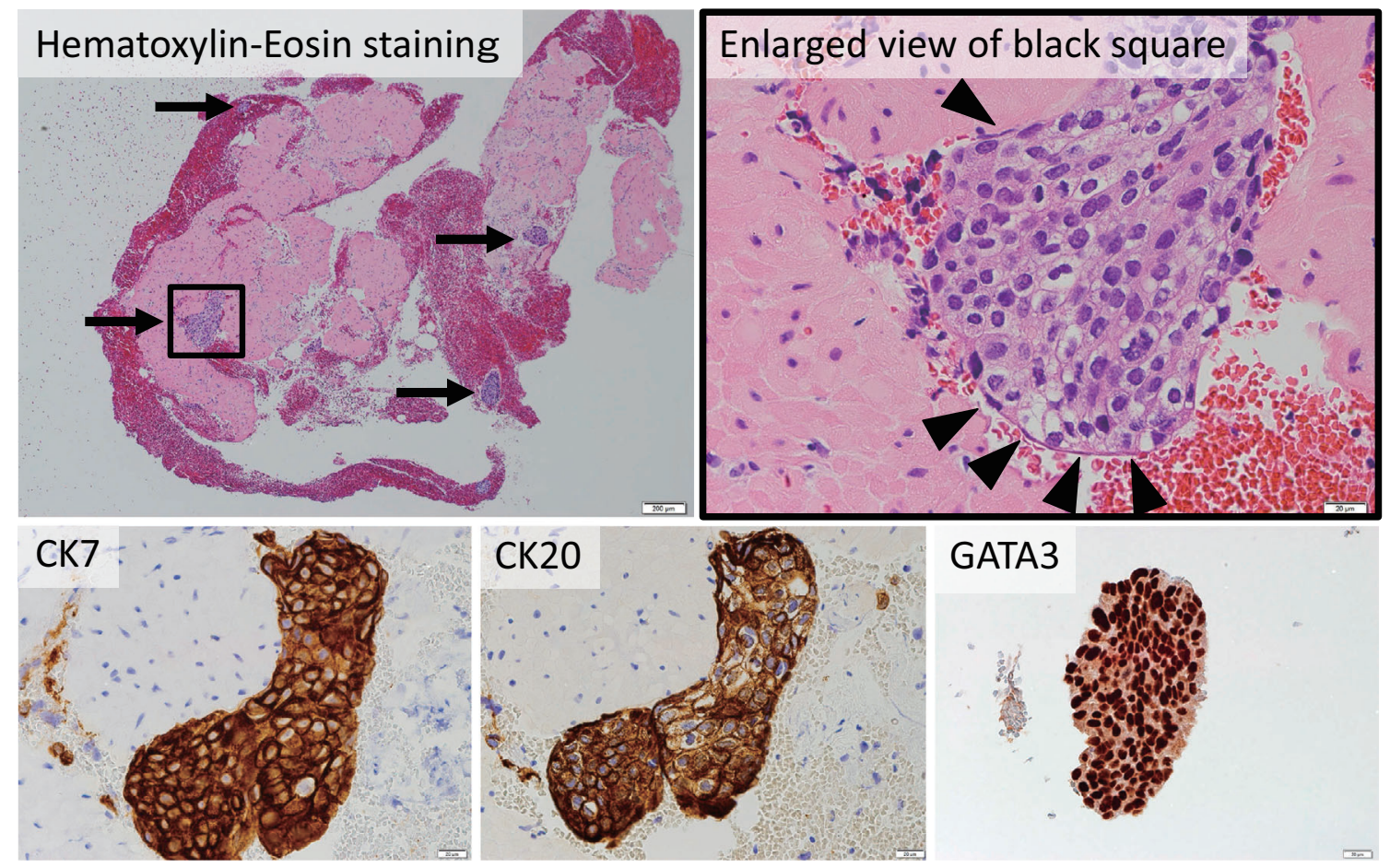

Figure 4. The histopathological examination of EUS-FNA specimens. Cancer nests surrounded by lymphatic endothelial cells (arrowheads) were identified in the duodenal tissues (arrows). The immunostaining findings were as follows: CK7, positive; CK20, positive; and GATA3, positive. EUS-FNA: endoscopic ultrasound-guided fine needle aspiration

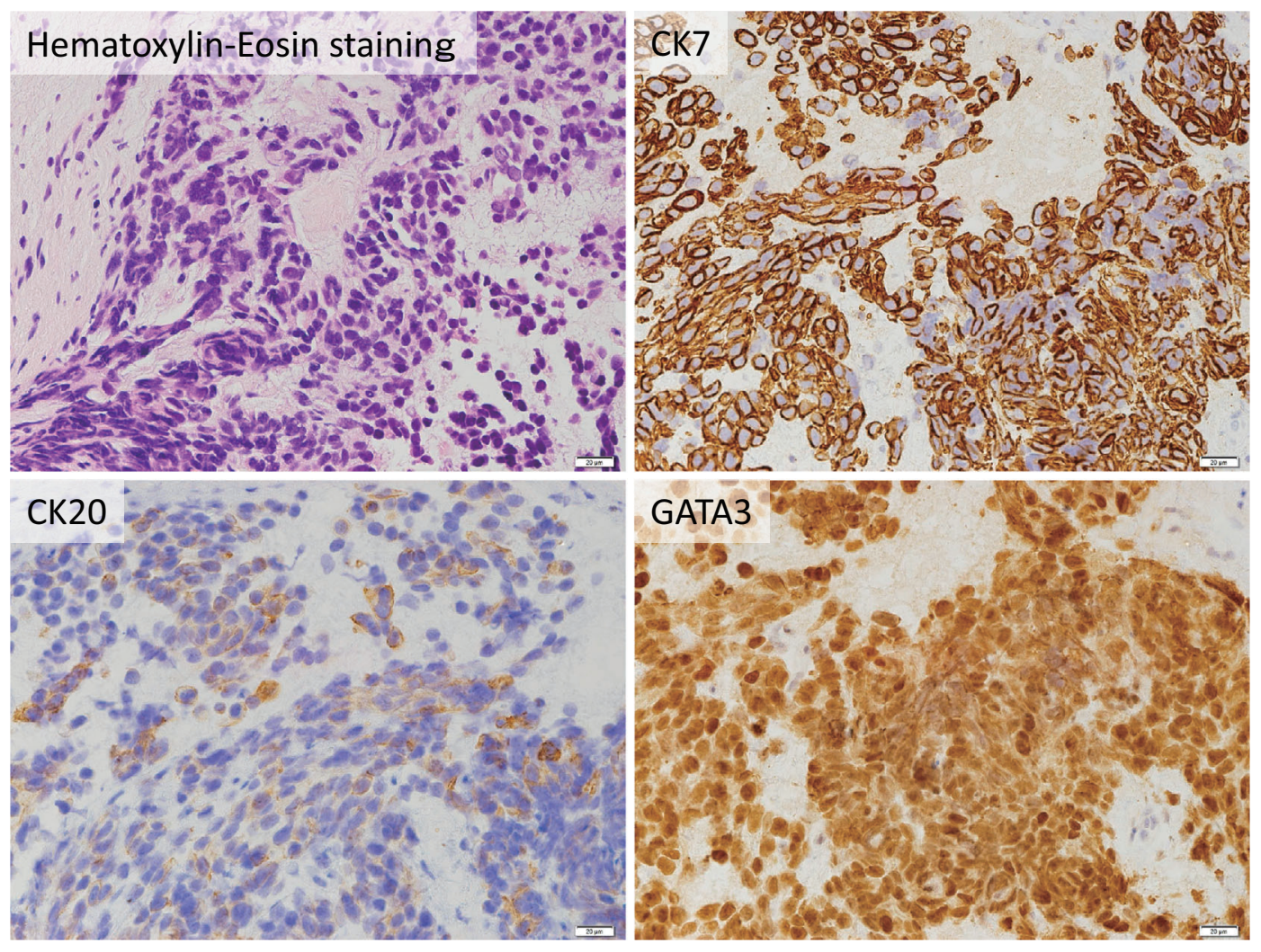

Figure 5. The histopathological examination of the tumor biopsy specimens by ureteroscopy. The pathological examination revealed transitional cell carcinoma of the right ureteral tract. The immunostaining findings were as follows: CK7, positive; CK20, positive; and GATA3, positive. 
Table. Reported Cases of Duodenal Stenosis with Upper Tract Urothelial Carcinoma.

\begin{tabular}{|c|c|c|c|c|c|c|c|c|c|}
\hline No & Reference & Age & Sex & Initial symptom & Endoscopy & $\mathrm{CT}$ & $\begin{array}{l}\text { Clinical } \\
\text { diagnosis }\end{array}$ & $\begin{array}{l}\text { Diagnosis } \\
\text { method }\end{array}$ & $\begin{array}{l}\text { The pathway to } \\
\text { the duodenum }\end{array}$ \\
\hline 1 & 13 & 61 & M & $\begin{array}{c}\text { Dysphagia } \\
\text { Upper abdominal } \\
\text { pain }\end{array}$ & $\begin{array}{l}\text { Generalized } \\
\text { inflammation }\end{array}$ & $\begin{array}{l}\text { Duodenal compression } \\
\text { at horizontal part } \\
\text { Left upper ureteric mass } \\
\text { Left hydronephrosis }\end{array}$ & $\begin{array}{c}\text { Urinary } \\
\text { carcinoma }\end{array}$ & $\begin{array}{l}\text { Laparoscopic } \\
\text { biopsy }\end{array}$ & Direct invasion \\
\hline 2 & 14 & 68 & $\mathrm{~F}$ & $\begin{array}{l}\text { No abdominal } \\
\text { symptoms }\end{array}$ & $\begin{array}{c}\text { Duodenal stricture } \\
\text { with edematous } \\
\text { mucosa }\end{array}$ & $\begin{array}{l}\text { Low density areas } \\
\text { surrounding the } \\
\text { duodenum } \\
\text { Bilateral hydronephrosis }\end{array}$ & $\begin{array}{c}\text { Urinary } \\
\text { carcinoma }\end{array}$ & EUS-FNA & $\begin{array}{c}\text { Peritoneal } \\
\text { dissemination }\end{array}$ \\
\hline 3 & 11 & 66 & M & $\begin{array}{c}\text { Vomiting } \\
\text { Upper abdominal } \\
\text { pain }\end{array}$ & $\begin{array}{c}\text { Circumferential } \\
\text { duodenal stenosis at } \\
\text { descending part }\end{array}$ & $\begin{array}{l}\text { Low density area at } \\
\text { pancreatic head } \\
\text { Right hydronephrosis }\end{array}$ & $\begin{array}{c}\text { Groove } \\
\text { pancreatitis }\end{array}$ & surgery & $\begin{array}{c}\text { Peritoneal } \\
\text { dissemination }\end{array}$ \\
\hline 4 & 12 & 83 & M & $\begin{array}{l}\text { Vomiting } \\
\text { Upper abdominal } \\
\text { pain }\end{array}$ & $\begin{array}{c}\text { Circumferential } \\
\text { duodenal stenosis at } \\
\text { descending part }\end{array}$ & $\begin{array}{c}\text { Duodenal obstruction at } \\
\text { descending part } \\
\text { Right hydronephrosis }\end{array}$ & $\begin{array}{l}\text { Unknown } \\
\text { primary } \\
\text { cancer }\end{array}$ & autopsy & $\begin{array}{l}\text { Lymphatic } \\
\text { metastasis }\end{array}$ \\
\hline 5 & Our case & 59 & M & $\begin{array}{l}\text { Vomiting } \\
\text { Upper abdominal } \\
\text { pain }\end{array}$ & $\begin{array}{c}\text { Circumferential } \\
\text { duodenal stenosis at } \\
\text { descending part with } \\
\text { multiple red spot }\end{array}$ & $\begin{array}{c}\text { Duodenal wall thickness } \\
\text { of descending part } \\
\text { Right hydronephrosis }\end{array}$ & $\begin{array}{l}\text { Duodenal } \\
\text { cancer }\end{array}$ & EUS-FNA & $\begin{array}{l}\text { Lymphatic } \\
\text { metastasis }\end{array}$ \\
\hline
\end{tabular}

M: male, F: female, CT: computed tomography, EUS-FNA: endoscopic ultrasound-guided fine needle aspiration

lial carcinoma infiltrated the walls of the bladder, rectum and duodenum. Considering the clinical course, they concluded that recurrent cancer in the bladder wall had infiltrated the rectum and duodenum as it spread widely into the retroperitoneal lymphatic vessels. On the other hand, in cases of peritoneal dissemination, cancer cells are considered to mainly be concentrated in the serosal layer of the duodenum; these cases frequently co-occur with massive ascites or pancreatic findings (11). In our present case, cancer cells seemed to be identified in the lymphatic vessels of the duodenal wall, although specimens obtained by EUS-FNA were tiny in comparison to the surgically resected specimens. These findings strongly suggested that the metastatic pathway of UTUC to the duodenum was via lymphatic dissemination.

The tumor architecture of UTUC is macroscopically categorized as either papillary or sessile. The sessile growth pattern of UTUC has been reported to be associated with a higher tumor grade, more advanced stage, lymphovascular invasion, and lymph node metastasis (16). Ricardo et al. demonstrated that the decreased expression of E-cadherin was associated with sessile architecture (17). Murakami et al. reported that the expression of $\mathrm{N}$-cadherin independently predicted recurrence after radical nephroureterectomy (18). Recent studies have demonstrated that a switch from Ecadherin to $\mathrm{N}$-cadherin in cancer cells plays an important role in the malignant progression by enhancing the motile and invasive potential $(18,19)$. These results may support that the duodenal stenosis appeared before hematuria and hydronephrosis in the present case, which showed sessile architecture.

The safety and outcomes of EUS-FNA have previously been analyzed (20-22), and its methods have been well established for sampling unexplained thickening of the esophagogastric wall and the diagnosis of linitis plastica in cases with negative endoscopic biopsy findings (23-27). Among 10 patients with unexplained thickening of the esophagogastric wall, five were diagnosed with carcinoma (esophageal carcinoma, $n=2$; gastric carcinoma, $n=3$ ) without complications using EUS-FNA (25). In cases of linitis plastica, the diagnostic accuracy of EUS-FNA was $87.5 \%$ (14/16), without severe hemorrhage or perforation (27). However, few studies exist regarding the use of EUS-FNA for duodenal lesions, except for the ampulla of Vater $(28,29)$. Indeed, only one case report has demonstrated the usefulness of EUS-FNA in the diagnosis of undiagnosed wall thickening of the duodenum due to diffuse large B-cell lymphoma and UTUC (14). In previous reports on the diagnosis of UTUC with duodenum involvement, the diagnosis was made during surgery or autopsy because of poor mucosal change in the duodenum (11-13) (Table). In our case, EUS-FNA provided an accurate diagnosis, and we could select the appropriate treatment without the need for invasive surgical procedures. We therefore suggest EUSFNA should be performed for the diagnosis of unexplained thickening of the duodenum in cases that meet the following criteria: 1) a conventional forceps biopsy has failed to diagnose the lesion; 2) duodenal wall thickening $(>5 \mathrm{~mm})$ is present; and 3) no visible interposing vessels are present on the estimated puncture line.

In conclusion, we experienced a case of UTUC with upper abdominal symptoms due to duodenal stenosis that presented before the appearance of hydronephrosis, in which EUS-FNA was useful for reaching a diagnosis. EUS-FNA can be an effective method for investigating unexplained thickening of the duodenal wall in cases with negative endoscopic biopsy findings.

The authors state that they have no Conflict of Interest (COI). 


\section{References}

1. Hirokaga K, Yoshida A, Ishikawa Y. A case of the duodenal crohn's disease presented with duodenal stenosis in the elderly. Nihon Rinsho Geka Gakkai Zasshi (J Japan Surg Assoc) 61: 17861791, 2000 (in Japanese, Abstract in English).

2. Tsutsui T, Asai H, Mizushima Y, Takagi R, Johnishi H, Shimodan M. Tuberculosis of the small intestine with duodenal stenosis. Nihon Rinsho Geka Gakkai Zasshi (J Japan Surg Assoc) 39: 534539, 1978 (in Japanese).

3. Chatani N, Hotei H, Murao N, Tahara K, Maeda Y, Miyoshi N. A case of retroperotoneal panniculitis causing duodenal stenosis. Nihon Rinsho Geka Gakkai Zasshi (J Japan Surg Assoc) 69: 183187, 2008 (in Japanese, Abstract in English).

4. Harada F, Mori R, Misuta K, Hasegawa S, Eguchi K, Nakano A. A case of metastatic duodenal carcinoma from bladder. Nihon Gekakei Rengo Gakkaishi (J Jpn Coll Surg) 36: 947-953, 2011 (in Japanese, Abstract in English).

5. Minato $\mathrm{T}$, Ishikawa $\mathrm{M}$, Takizawa $\mathrm{H}$, et al. A case of duodenal stenosis caused by mucinous carcinoma of the appendix. Nihon Fukubu Kyukyu Igakkai Zasshi (J Abdom Emerg Med) 32: 703706, 2012 (in Japanese, Abstract in English).

6. Shimada Y, Yoshida H, Adachi K, Itani T, Mimura J, Hashimoto $\mathrm{K}$. A case of poorly differentiated adenocarcinoma of the duodenum with a diffuse invasive pattern. Gastroenterol Endosc 58: 2412-2417, 2016 (in Japanese, Abstract in English).

7. Ohyama S, Konishi I, Nagakawa T, et al. A case of right renal pelvic carcinoma appeared by the duodenal stenosis. The Japanese journal of gastroenterological surgery 19: 2304-2307, 1986 (in Japanese).

8. Roupret M, Babjuk M, Comperat E, et al. European Association of Urology Guidelines on Upper Urinary Tract Urothelial Carcinoma: 2017 Update. Eur Urol 73: 111-122, 2018.

9. Mathieu R, Bensalah K, Lucca I, Mbeutcha A, Roupret M, Shariat S. Upper urinary tract disease: what we know today and unmet needs. Transl Androl Urol 4: 261-272, 2015.

10. Messer J, Shariat S, Brien J, et al. Urinary cytology has a poor performance for predicting invasive or high-grade upper-tract urothelial carcinoma. BJU Int 108: 701-705, 2011.

11. Takiuchi D, Morimoto O, Wada R, et al. A case of urothelial carcinoma who underwent pancreaticoduodenectomy and was diagnosed with groove pancreatitis and preoperatively suffered from duodenal stenosis. Gan To Kagaku Ryoho (Cancer Chemother) 44: 2003-2005, 2017 (in Japanese, Abstract in English).

12. Ando T, Watanabe K, Takahashi K, Mizusawa T, Sakai T, Katagiri A. Duodenal and rectal obstructions due to urothelial cancer infiltration from recurrent renal pelvic cancer in the bladder wall: an autopsy case. Urol Case Rep 27: 1-4, 2019.

13. Stroman LA, Sharma N, Sullivan M. Upper ureteric transitional cell carcinoma, extending to the renal pelvis, presenting as duodenal obstruction. BMJ Case Rep 2015: bcr2015210028, 2015.

14. Nakai Y, Isayama H, Takahara N, et al. Endoscopic ultrasoundguided fine-needle aspiration for duodenal obstruction without a discrete mass. Dig Dis Sci 60: 1502-1504, 2015.

15. Tanaka N, Kikuchi E, Kanao K, et al. Metastatic behavior of upper tract urothelial carcinoma after radical nephroureterectomy: association with primary tumor location. Ann Surg Oncol 21: 1038-
1045, 2014.

16. Mesut R, Andrea H, Vitaly M, et al. Tumor architecture is an independent predictor of outcomes after nephroureterectomy:a multiinstitutional analysis of 1363 patients. BJU Int 103: 307-311, 2008.

17. Ricardo L, Atessa B, Romain M, et al. Prognostic role of decreased E-cadherin expression in patients with upper tract urothelial carcinoma: a multi-institutional study. World J Urol 35: 113120, 2017.

18. Murakami M, Miyake H, Terakawa T, Kusuda Y, Fujisawa M. Expression profile of E-cadherin and $\mathrm{N}$-cadherin in urothelial carcinoma of the upper urinary tract is associated with disease recurrence in patients undergoing nephroureterectomy. Urology 78: 1443e7-1443e12, 2011.

19. Margaret JW, Shintani Y, Maeda M, Fukumoto Y, Keith RJ. Cadherin switching. J Cell Sci 121: 727-735, 2008.

20. Yasuda I, Goto N, Tsurumi H, et al. Endoscopic ultrasound-guided fine needle aspiration biopsy for diagnosis of lymphoproliferative disorders: feasibility of immunohistological, flow cytometric, and cytogenetic assessments. Am J Gastroenterol 107: 397-404, 2012.

21. Yamao K, Sawaki A, Mizuno N, Shimizu Y, Yatabe Y, Koshikawa T. Endoscopic ultrasound-guided fine-needle aspiration biopsy (EUS-FNAB): past, present, and future. J Gastroenterol 40: 10131023, 2005.

22. Vander Noot MR 3rd, Eloubeidi MA, Chen VK, et al. Diagnosis of gastrointestinal tract lesions by endoscopic ultrasound-guided fine-needle aspiration biopsy. Cancer 102: 157-163, 2004.

23. Liu Y, Chen K, Yang XJ. Endoscopic ultrasound-guided fineneedle aspiration used in diagnosing gastric linitis plastica: Metastatic lymph nodes can be valuable targets. J Gastroenterol Hepatol 34: 202-206, 2019.

24. Muraoka S, Tsuchida K, Iwasaki M, et al. A case report of gastric linitis plastica diagnosed by endoscopic ultrasound-guided fine needle aspiration. Medicine 96: 1-5, 2017.

25. Aithal GP, Anagnostopoulos GK, Kaye P. EUS-guided Trucut mural biopsies in the investigation of unexplained thickening of the esophagogastric wall. Gastrointest Endosc 62: 624-629, 2005.

26. Thomas T, Kaye PV, Ragunath K, Aithal GP. Endoscopicultrasound-guided mural trucut biopsy in the investigation of unexplained thickening of esophagogastric wall. Endoscopy 41: 335339, 2009.

27. Ye Y, Tan S. Endoscopic ultrasound-guided fine-needle aspiration biopsy for diagnosis of gastric linitis plastica with negative malignant endoscopy biopsies. Oncol Lett 16: 4915-4920, 2018.

28. Defrain C, Chang CY, Srikureja W, Nguyen PT, Gu M. Cytologic features and diagnostic pitfalls of primary ampullary tumors by endoscopic ultrasound-guided fine-needle aspiration biopsy. Cancer 105: 289-297, 2005.

29. Ogura T, Hara K, Hijioka S, et al. Can endoscopic ultrasoundguided fine needle aspiration offer clinical benefit for tumors of the ampulla of vater?--an initial study. Endosc Ultrasound 1: 8489, 2012 .

The Internal Medicine is an Open Access journal distributed under the Creative Commons Attribution-NonCommercial-NoDerivatives 4.0 International License. To view the details of this license, please visit (https://creativecommons.org/licenses/ by-nc-nd/4.0/).

(C) 2021 The Japanese Society of Internal Medicine Intern Med 60: 719-724, 2021 